Indian Journal of Clinical Biochemistry, 2006, 21 (1) 104-108

\title{
LIPID PEROXIDATION AND ANTIOXIDANT STATUS IN BLOOD OF RHEUMATOID ARTHRITIS PATIENTS
}

\author{
D. Vijayakumar, K. Suresh and S. Manoharan*
}

Department of Biochemistry, Faculty of Science, Annamalai University, Annamalai Nagar - 608 002, India

\begin{abstract}
The main objective of the study was to assess the oxidative stress in plasma and erythrocytes of rheumatoid arthritis patients by measuring the levels of thiobarbituric acid reactive substances (TBARS), non-enzymatic antioxidants (vitamin E, C and reduced glutathione) and enzymatic antioxidants [superoxide dismutase (SOD), catalase (CAT) and glutathione peroxidase (GSHPx)]. This study has been conducted on twenty-two adult female rheumatoid arthritis patients and an equal number of healthy subjects. Elevated lipid peroxidation and multidirectional changes in the antioxidant defence system were noticed in patients with rheumatoid arthritis. The enhanced lipid peroxidation accompanied by disturbance in antioxidant status indicates that rheumatoid arthritis patients are more prone to free radical mediated oxidative damage.
\end{abstract}

\section{KEYWORDS}

Rheumatoid arthritis, lipid peroxidation, antioxidants.

\section{INTRODUCTION}

Free radicals, the highly reactive entity and very shortlived molecules, are constantly produced in a wide variety of normal physiological functions. Although free radicals perform some useful functions, they are toxic when generated in excess [1]. The most important characteristic of toxic free radicals either in vivo or in vitro is peroxidation of lipids resulting in tissue damage and death of affected cells [2]. The profound body of evidence implicating that free radical induced lipid peroxidation in the pathogenesis of various pathological conditions including chronic inflammatory conditions [3, 4]. The harmful effect of reactive oxygen species is neutralized by a broad class of protective agents termed antioxidants which prevents oxidative damage by reacting with free radicals before any other molecules can become a target. The non-enzymatic antioxidants (vitamin $\mathrm{E}, \mathrm{C}$ and reduced glutathione) and antioxidant enzymes (SOD, CAT, GSHPx) play an important role in the protection of cells and tissues against free radical mediated tissue damage $[5,6]$.

Rheumatoid arthritis is a chronic systemic

\section{Author for Correspondence :}

Dr. S. Manoharan, Ph.D., Sr. Lecturer,

Department of Biochemistry,

Faculty of Science,

Annamalai University,

Annamalai Nagar-608 002, Tamilnadu, India

e-mail : manshisak@yahoo.com inflammatory disorders of unknown cause that affects approximately $1 \%$ of world population [7]. Oxidative stress has been implicated in the pathogenesis of rheumatoid arthritis [8]. Gambhir et al. [9] reported significantly increased lipid peroxidation, higher erythrocytes glutathione, and unaltered erythrocytes antioxidant enzymes in rheumatoid arthritis patients as compared to healthy subjects. Taysi et al. [10] have reported an elevated serum malondialdehyde, $\mathrm{Cu}-\mathrm{Zn}$ superoxide dismutase activity and decreased activities of glutathione peroxidase and catalase in rheumatoid arthritis patients than in healthy controls. Braven et al. [11] have reported an increase in erythrocytes glutathione peroxidase activity in rheumatoid arthritis patients as compared to healthy controls.

Although the status of lipid peroxidation and antioxidants has been reported in patients with rheumatoid arthritis, the results of previous studies were controversial from one another. Thus, the present study was carried out to provide a clear picture on blood lipid peroxidation and antioxidant status in rheumatoid arthritis patients by carrying out a simultaneous study in both plasma and erythrocytes of adult female rheumatoid arthritis patients.

\section{PATIENTS AND METHODS}

Twenty-two rheumatoid arthritis patients from Rajah Muthaiah Medical College and Hospital, Annamalai University, Annamalainagar, India, were chosen for the study. An equal number of healthy subjects were also investigated. The subjects were female ranging in age from $40-60$ years. All the patients in the present study 
were clinically diagnosed as patients with rheumatoid arthritis. The diagnosis of rheumatoid arthritis was done based on 1988 revised American Rheumatism Association (ARA) for classification of rheumatoid arthritis. The healthy subjects and patients were not habituated to smoking and/or alcohol consumption and were diagnosed as being free from any other systemic diseases.

Fasting blood samples were obtained by antecubital vein into heparinized tubes. Plasma was separated by centrifugation at $1,000 \mathrm{~g}$ for 15 minutes. The buffy coat was removed and packed cells were washed three times with physiological saline. The erythrocyte membranes were prepared by the method of Dodge et al. [12] modified by Quist [13].

Thiobarbituric acid reactive substances (TBARS) released from endogenous lipoperoxides, reflecting the lipid peroxidation process, were assayed in plasma as described by Yagi (14) and in erythrocytes as described by Donnan (15). The levels of non enzymatic antioxidants were estimated by the method of Desai (16). [vitamin E], Omaye et al. (17) [vitamin C] and Beutler and Kelly (18) [reduced glutathione]. The level of ceruloplasmin was measured by the method of Ravin (19). The activities of antioxidant enzymes were determined by the method of Rotruck et al. (20)[GSHPX], Kakkar (21) [SOD] and Sinha (22) [CAT].

\section{STATISTICAL ANALYSIS}

The data are expressed as mean \pm SD. Statistical comparisons were performed by Student's 't' test. The null hypothesis was rejected for $p<0.05$.

\section{RESULTS}

Table 1 shows the levels of TBARS in plasma, erythrocytes and erythrocyte membranes of healthy subjects and rheumatoid arthritis patients. The TBARS levels were significantly increased $(p<0.001)$ in rheumatoid arthritis patients as compared to healthy subjects.

Table 2 shows the levels of non enzymatic antioxidants (vitamin C, E, reduced glutathione and ceruloplasmin) in plasma, erythrocytes and erythrocyte membranes of healthy subjects and rheumatoid arthritis patients. The level of vitamin $\mathrm{C}$ in plasma and the level of vitamin $E$ in plasma and erythrocyte membrane were significantly decreased $(p<0.001)$ in rheumatoid arthritis patients as compared to healthy subjects. The level of reduced glutathione was decreased in plasma $(p<0.01)$ whereas increased $(p<0.001)$ in erythrocytes of rheumatoid arthritis patients as compared to healthy subjects. The levels of plasma ceruloplasmin were significantly increased $(p<0.001)$ in rheumatoid arthritis patients as compared
Table 1. TBARS levels in healthy subjects and rheumatoid arthritis patients

\begin{tabular}{|ccc|}
\hline Parameters & $\begin{array}{c}\text { Healthy } \\
\text { subjects }\end{array}$ & $\begin{array}{c}\text { Rheumatoid } \\
\text { arthritis } \\
\text { patients }\end{array}$ \\
\hline $\begin{array}{l}\text { Plasma } \\
\text { TBARS } \\
(\mathrm{n} \mathrm{mol} / \mathrm{ml})\end{array}$ & $3.09 \pm 0.3$ & $6.58 \pm 0.49^{* *}$ \\
$\begin{array}{l}\text { Erthrocytes } \\
\text { TBARS } \\
\text { (p mol/mg. Hb) }\end{array}$ & $3.41 \pm 0.31$ & $7.01 \pm 0.81^{* *}$ \\
$\begin{array}{l}\text { Erythrocyte } \\
\text { membranes } \\
\text { TBARS } \\
\text { (n mol/mg protein) }\end{array}$ & $0.31 \pm 0.02$ & $1.32 \pm 0.13^{* *}$ \\
\hline
\end{tabular}

Values are expressed as mean \pm S.D.; $n=22$

** Significantly different from healthy subjects,

$P<0.001$

Table 2. Levels of non-enzymatic antioxidants in healthy subjects and rheumatoid arthritis patients

\begin{tabular}{|c|c|c|}
\hline Parameters & $\begin{array}{l}\text { Healthy } \\
\text { subjects }\end{array}$ & $\begin{array}{c}\text { Rheumatoid } \\
\text { arthritis } \\
\text { patients }\end{array}$ \\
\hline \multicolumn{3}{|l|}{ Plasma } \\
\hline $\begin{array}{l}\text { Vitamin } C \\
(\mathrm{mg} / \mathrm{dl})\end{array}$ & $1.36 \pm 0.15$ & $0.82 \pm 0.07^{* *}$ \\
\hline $\begin{array}{l}\text { Vitamin } E \\
(\mathrm{mg} / \mathrm{dl})\end{array}$ & $1.24 \pm 0.14$ & $0.79 \pm 0.09^{* *}$ \\
\hline $\begin{array}{l}\text { Reduced } \\
\text { glutathione } \\
(\mathrm{mg} / \mathrm{dl})\end{array}$ & $44.9 \pm 4.82$ & $40.6 \pm 3.94^{*}$ \\
\hline $\begin{array}{l}\text { Ceruloplasmin } \\
(\mathrm{mg} / \mathrm{dl})\end{array}$ & $23.6 \pm 2.60$ & $32.34 \pm 2.60^{* *}$ \\
\hline \multicolumn{3}{|l|}{ Erthrocytes } \\
\hline $\begin{array}{l}\text { Reduced } \\
\text { glutathione } \\
(\mathrm{mg} / \mathrm{dl})\end{array}$ & $46.9 \pm 5.10$ & $62.8 \pm 4.11^{* *}$ \\
\hline \multicolumn{3}{|l|}{$\begin{array}{l}\text { Erythrocyte } \\
\text { membranes }\end{array}$} \\
\hline $\begin{array}{l}\text { Vitamin } \mathrm{E} \\
\text { ( } \mathrm{g} / \mathrm{mg} \text { protein) }\end{array}$ & $2.09 \pm 0.12$ & $1.67 \pm 0.11^{* *}$ \\
\hline
\end{tabular}

Values are expressed as mean \pm S.D.; $n=22$

** Significantly different from healthy subjects, $P<0.001$

* Significantly different from healthy subjects,

$P<0.01$ 
to healthy subjects.

Table 3 shows the activities of plasma glutathione peroxidase, superoxide dismutase and catalase in healthy subjects and rheumatoid arthritis patients. The glutathione peroxidase and catalase activities were moderately decreased $(p<0.01)$ whereas the superoxide dismutase (SOD) activity was moderately increased $(p<0.01)$ in rheumatoid arthritis patients as

Table 3. Plasma enzymatic antioxidants activities in healthy subjects and rheumatoid arthritis patients

\begin{tabular}{|c|c|c|}
\hline Parameters & $\begin{array}{l}\text { Healthy } \\
\text { subjects }\end{array}$ & $\begin{array}{c}\text { Rheumatoid } \\
\text { arthritis } \\
\text { patients }\end{array}$ \\
\hline \multicolumn{3}{|l|}{ Plasma } \\
\hline $\begin{array}{l}\text { Glutathione } \\
\text { peroxidase } \\
\left(\mathrm{U}^{\mathrm{a} / \mathrm{ml})}\right.\end{array}$ & \multicolumn{2}{|c|}{$0.238 \pm 0.0210 .218 \pm 0.020^{*}$} \\
\hline $\begin{array}{l}\text { Superoxide } \\
\text { dismutase } \\
\left(\mathrm{U}^{\mathrm{b}} / \mathrm{ml}\right)\end{array}$ & $4.40 \pm 0.60$ & $5.24 \pm 0.82^{*}$ \\
\hline $\begin{array}{l}\text { Catalase } \\
\left(\mathrm{U}^{c} / \mathrm{ml}\right)\end{array}$ & $1.56 \pm 0.18$ & $1.46 \pm 0.11^{*}$ \\
\hline
\end{tabular}

Values are expressed as mean \pm S.D.; $n=22$

* Significantly different from healthy subjects,

$P<0.01$

a moles of reduced glutathione utilized/minute

b $50 \%$ inhibition of NBT reduction

c moles of hydrogen peroxide consumed/minute.

compared to healthy subjects.

Table 4 shows the activities of glutathione peroxidase, superoxide dismutase and catalase in erythrocyte lysate of healthy subjects and rheumatoid arthritis patients. The glutathione peroxidase activity was significantly increased $(p<0.001)$ whereas superoxide dismutase and catalase activities were moderately decreased $(p<0.01)$ in rheumatoid arthritis patients as compared to healthy subjects.

\section{DISCUSSION}

Rheumatoid arthritis is one of the most common inflammatory diseases worldwide. In the present study, elevated levels of TBARS and multidirectional antioxidant status were noticed in patients with rheumatoid arthritis as compared to healthy subjects.

Inflammation and tissue injury related oxidative stress has been implicated in the pathogenesis of rheumatoid arthritis (23). Free radicals are enormously produced at the site of inflammation and tissue injuries (24). Lipid peroxides that are generated at the site of
Table 4. Erythrocytes enzymatic antioxidants activities in healthy subjects and rheumatoid arthritis patients

\begin{tabular}{|c|c|c|}
\hline Parameters & $\begin{array}{l}\text { Healthy } \\
\text { subjects }\end{array}$ & $\begin{array}{c}\text { Rheumatoid } \\
\text { arthritis } \\
\text { patients }\end{array}$ \\
\hline \multicolumn{3}{|l|}{$\begin{array}{l}\text { Erythrocyte } \\
\text { hemolysate }\end{array}$} \\
\hline $\begin{array}{l}\text { Glutathione } \\
\text { peroxidase } \\
\left(\mathrm{U}^{\mathrm{a} / \mathrm{I} \mathrm{Hb})}\right)\end{array}$ & $27.6 \pm 2.80$ & $42.5 \pm 3.90^{* *}$ \\
\hline $\begin{array}{l}\text { Superoxide } \\
\text { dismutase } \\
\left(\mathrm{U}^{\mathrm{b}} / \mathrm{mg} \mathrm{Hb}\right)\end{array}$ & $2.40 \pm 0.26$ & $2.15 \pm 0.28^{*}$ \\
\hline 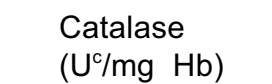 & $1.56 \pm 0.18$ & $1.46 \pm 0.11^{*}$ \\
\hline
\end{tabular}

Values are expressed as mean \pm S.D.; $n=22$

* Significantly different from healthy subjects,

$\mathrm{P}<0.001$

* Significantly different from healthy subjects,

$\mathrm{P}<0.01$

a moles of reduced glutathione utilized/minute

b $50 \%$ inhibition of NBT reduction

c moles of hydrogen peroxide consumed/minute.

inflammation of tissue injury diffuses into blood and can be estimated in serum or plasma, which inturn reflect the severity of the tissue damage (25). Susceptibility of erythrocytes to peroxide stress is increased in several diseased conditions (26). Thus, the elevated plasma lipid peroxidation observed in the present study in rheumatoid arthritis patients can be related to excessive lipid peroxidation observed in erythrocytes and erythrocyte membranes, with consequent leakage into plasma or as a result of excessive generation and diffusion of lipid peroxides from the inflammed or injured joints of rheumatoid arthritis.

In the present study, we have observed a multidirectional changes of non enzymatic and enzymatic antioxidants as compared to healthy subjects. Vitamin E, Vitamin $C$ and reduced glutathione, a well known antioxidants, play an important role in protecting the lipids of lipoproteins and other biomembranes against peroxidative damage by intercepting oxidants before they can attack the tissues (27). Lower concentration of vitamin $E$ has been reported in the joint fluid of patients with rheumatoid arthritis (28). An inverse relationship between lipid peroxidation and non enzymatic antioxidants has been well documented $[29,30]$. Hence, the decrease in plasma non enzymatic 
Indian Journal of Clinical Biochemistry, 2006, 21

antioxidants can be correlated to impairment in the antioxidant defence mechanism, due to excess utilization by the inflammed tissues to scavenge the excessive lipid peroxides that are generated at inflammatory sites, or to scavenge accumulated lipid peroxides in plasma.

Glutathione peroxidase prevents the accumulation of oxidized lipids in mitochondrial cell membranes and also detoxifies $\mathrm{H}_{2} \mathrm{O}_{2}$ by utilizing reduced glutathione as a cosubstrate (31). Glutathione levels and glutathione peroxidase activity were decreased in plasma whereas increased in erythrocytes of rheumatoid arthritis patients as compared to healthy subjects. It has been reported that decrease in glutathione, a cosubstrate of glutathione peroxidase, results in a greater susceptibility to oxidative stress (32). The altered activity of glutathione peroxidase in plasma or erythrocytes observed in the present study can therefore be related to the availability of reduced glutathione in plasma or erythrocytes.

Superoxide radicals play an important role as a chemical mediator on the inflammatory response of rheumatoid arthritis (33). Ceruloplasmin, coppercontaining protein, has been found to be increased in rheumatoid arthritis patients as compared to healthy subjects. Increased levels of ceruloplasmin observed in the present study may be related to its scavenging action of superoxide radicals that are generated during the inflammatory process of rheumatoid arthritis.

The increased activity of plasma superoxide dismutase observed in the present study could therefore be due to dismutate the excess superoxide radicals that are generated and diffused from the inflammatory sites into plasma. The hydrogen peroxide formed due to the above reaction could not have been detoxified due to lowered activity of plasma glutathione peroxidase and catalase observed in the present study. It has been demonstrated that the hydrogen peroxide produced due to dismutation of superoxide could possibly be converted to hydroxyl radical by iron released from haemoglobin of lysed erythrocytes (10, 34). The decrease in blood haemoglobin (10.4 \pm 1.1 $\mathrm{g} / \mathrm{dL}$ ) and reduction in erythrocyte count (3.62 \pm 0.37 $\times 10^{6}$ cells/ I) observed in rheumatoid arthritis patients in the present study lend credibility to these observations.

Superoxide dismutase and catalase, play an important role in the protection of erythrocytes from oxidative stress. Lowered activities of red cell catalase and superoxide dismutase have been reported in patients with rheumatoid arthritis [35, 36]. Our results lend credibility to these observations. The elevated lipid peroxidation in plasma and erythrocytes observed in the present study can therefore be related to compensatory changes in the antioxidant defence

\section{(1) $104-108$}

system of rheumatoid arthritis patients.

Thus, we feel that the overproduction of free radicals by the inflammatory processes of rheumatoid arthritis, causes potential oxidative injury to erythrocytes and erythrocyte membranes and damage their antioxidant defence system in rheumatoid arthritis patients.

\section{REFERENCES}

1. Parke, D.V. and Sapota, A. (1996). Chemical toxicity and reactive oxygen species. Int J Occup Med Environ Health. 9, 331-340.

2. Bandyopadhyay, U., Das, D. and Banerjee, R.K. (1999). Reactive oxygen species: Oxidative damage and pathogenesis. Current Sci. 77, 658666.

3. Halliwell, B. (1994). Free radicals, antioxidants and human disease: curiosity causes or consequences? Lancet. 344, 721-724.

4. Weitzman, S.A. and Gorden, L.I. (1990). Inflammation and cancer: role of phagocyte generated oxidants in carcinogenesis. Blood. 76, 655-663.

5. Yu, B.P. (1994). Cellular defences against damage from reactive oxygen species. Biol Rev. 74, 139-162.

6. Ray, G. and Husain, S.H. (2002). Oxidants, antioxidants and carcinogenesis. Indian J. Exp. Biol. 40, 1213-1232.

7. Deborah, P.M. (2002). Epidemiology of rheumatoid arthritis: determinants of onset, persistence and outcome. Clin. Rheum. 16, 707722.

8. Aruoma, O.I., Kaur, H. and Halliwell, B. (1991). Oxygen free radicals and human diseases. J. R. Soc. Health. 111, 172-177.

9. Gambhir, J.K., Lali, P. and Jain, A.K. (1997). Correlation between blood antioxidant levels and lipid peroxidation in rheumatoid arthritis. Clin. Biochem. 30, 251-255.

10. Taysi, S., Polat, F., Gul, M., Sari, R.a. and Bakan, E. (2002). Lipid peroxidation, some extracellular antioxidants, and antioxidants enzymes in serum of patients with rheumatoid arthritis. Rheumatol. Int. 21, 200-204.

11. Braven, J., Ansari, N., Figgitt, D.P., Fisher, A., Luders, C., Hickling, P. and Whittaker, M. (1989). A comparison of glutathione reductase and glutathione peroxidase activities in patients with rheumatoid arthritis and healthy adults. $\mathrm{Br}$. J. 
Indian Journal of Clinical Biochemistry, 2006, 21 (1) 104-108

Rheumatol. 28, 212-215.

12. Dodge, J.F., Mitchell, G. and Hanahan, D.J. (1968). The preparation and chemical characterization of haemoglobin free ghosts of human red blood cells. Arch. Biochem. Bio. Phys.110, 119-130.

13. Quist, E.H. (1980). Regulation of erythrocyte membrane shape by calcium ion. Biochem. Biophys. Res. Commun. 92, 631-637.

14. Yagi, K. (1978). Lipid peroxides and human disease. Chem. Physiol. Lip. 45, 337-357.

15. Donnan, S.K. (1950). The thiobarbituric acid test applied to tissues from rats treated in various ways. J. Biol. Chem. 18, 415-419.

16. Desai, F.D. (1984). Vitamin E analysis methods for animal tissues. In: Feischer S, Packer L, eds. Methods Enzymol, vol.105. Academic Press, New York.138-145.

17. Omaye, S.T., Turubull, T.D. and Sauberlich, H.E. (1979). Selected method for the determination of ascorbic acid in animal cells, tissues and fluids. In: Mc Cormic D, Band Wright DL, eds. Methods Enzymol, vol.62. Academic Press, New York. 311.

18. Beutler, E. and Kelley, B.M. (1963). The effect of sodium nitrate on RBC glutathione. Experientia. 19, 96-97.

19. Ravin, H.A. (1961). An improved colorimetric enzymatic assay for ceruloplasmin. J. Lab. Clin. Med. 58, 161-168.

20. Rotruck, J.T., Pope, A.L., Ganther, H.E., Swanson, A.B., Hafeman, D.G. and Hoekstra, W.G. Selemium. (1973). Biochemical roles as a component of glutathione peroxidase. Science. 179, 588-590.

21. Kakkar, P., Das, B. and Viswanathan, P.N. (1984). A modified spectrophotometric assay of superoxide dimutase. Indian J. Biochem. Bio. Phys. 21, 130-132.

22. Sinha, K.A. (1972). Colorimetric assay of catalase. Annal. Biochem. 47, 389-394.

23. Ostrakhovitch, E.A. and Afanas'ev, I.B. (2001). Oxidative stress in rheumatoid arthritis leukocytes: suppression by rutin and other antioxidants and chelators. Biochem. Pharmacol. $62,743-746$.

24. Gotia, S., Popovici, I. and Hermeziu, B. (2001). Antioxidant enzymes levels in children with juvenile rheumatoid arthritis. Rev. Med. Chair.
Soc. Med. Nat. lasi. 105, 499-503.

25. Gutteridge, J.M.C. (1995). Lipid peroxidation and antioxidants as biomarkers of tissue damage. Clin Chem. 41, 1819-1828.

26. Wagner, G.M., Lubin, B.H. and Yechin, D.T. (1998). Oxidative damage to red cells. In: cellular antioxidant defence mechanisms. Chow C.K. (ed.), CRC Press Inc: Boca Raton: 185-195.

27. Srinivas, K., Bhaskar, M., Aruna Kumari, R., Nagaraj, K. and Reddy, K.K. (2000). Antioxidants, lipid peroxidation and lipoproteins in primary hypertension. Indian Heart J. 52, 285-8.

28. Fairburn, K., Grootveld, M. and Ward, R.J. (1992). Alphatocopherol, lipids and lipoproteins in kneejoint synovial fluid and serum from patients with inflammatory joint disease. Clin. Sci. 83, 657-664.

29. Kolanjiappan, K., Manoharan, S. and Kayalvizhi, M. (2002). Measurement of erythrocyte lipids, lipid peroxidation, antioxidants and osmotic fragility in cervical cancer patients. Clin. Chin. Acta. 326, 143-149.

30. Manoharan, S., Shreeram, S. and Nagini, S. (1996). Life style can induce lipid peroxidation and compromise of antioxidant defence mechanisms in the erythrocyte of oral cancer patients. Med. Sci. Res. 24, 397-400.

31. Hassan, M.Q., Hadi, R.A., A1-Rawi, Z.S., Padron, V.A. and Stohs, S.J. (2001). The glutathione defense system in the pathogensis of rheumatoid arthritis. J. Appl. Toxicol. 21, 69-73.

32. Buettner, G.R. and Schafer, F.Q. (2000). Free radicals, Oxidants and Antioxidants. Teratology. 62, 234.

33. Kaneda, H. (1982). A study on the lipid peroxide and its scavenging enzymes in rheumatoid arthritis. Nippon Seikeigeka Gakkai Zasshi. 56, 387-397.

34. Cross, C.E., Halliwell, B., Borish, E.T., Pryor, W.A., Ames, B.N., Saul, R.L., Mccord, J.M. and Harman, D. (1987). Oxygen radicals and human disease. Ann. Rheum. Dis. 107, 526.

35. Karatas, F., Ozates, I., Canatan, H., Halifeoglu, I., Karatepe, M. and Colak, R. (2003). Antioxidant status and lipid peroxidation in patients with rheumatoid arthritis. Indian J. Med. Res. 118, 178181.

36. Imadaya, A., Teraswa, K., Tosa, H., Okamoto, M. and Toriizuka, K. (1998). Erythrocyte antioxidant enzymes are reduced in patients with rheumatoid arthritis. J. Rheumatol. 15, 1628-1631. 